\section{On some testacids (Protozoa) of Melghat Wildlife Sanctuary, Maharashtra, India}

\section{Bindu}

Zoological Survey of India, M-Block, New Alipore, Kolkata, West Bengal 700053, India

E-mail: bindulajapathi@yahoo.com

Melghat Wildlife Sanctuary located in Amaravathi District of Maharashtra State is spread over an area of $788.75 \mathrm{~km}^{2}$. Melghat literally means the meeting point of hills and this large compact block of hills is endowed with diverse flora and fauna. There is a dearth of information on protozoa of Melghat Wildlife Sanctuary and hence collections were made from three spots, viz., Semodah, Makhala and Kolkaz. Of the ten species of testacids (freeliving protozoa) reported here, nine species are new records to Maharashtra and one species is reported for the first time from India.

\section{Systematic account}

\section{Phylum: Sarcomastigophora}

Class: Lobosea

Order: Arcellinida

Three families are dealt under this order.

\section{Family: Microcoryciidae}

Genus: Amphizonella Greeff

Diagnosis: Test membraneous with a double marginal contour; inner membrane smooth, well defined; outer serrulate, aperture inverted, a single nucleus; pseudopodia

Date of publication (online): 26 April 2010

Date of publication (print): 26 April 2010

ISSN 0974-7907 (online) | 0974-7893 (print)

Editor: A.K. Das

Manuscript details:

Ms \# 02007

Received 19 June 2008

Final received 16 November 2009

Finally accepted 09 February 2010

Citation: Bindu, L. (2010). On some testacids (Protozoa) of Melghat Wildlife Sanctuary, Maharashtra, India. Journal of Threatened Taxa 2(4): $827-830$

Copyright: @ L. Bindu 2010. Creative Commons Attribution 3.0 Unported License. JoTT allows unrestricted use of this article in any medium for nonprofit purposes, reproduction and distribution by providing adequate credit to the authors and the source of publication.

Acknowledgements: The author is grateful to Dr. Ramakrishna, Director Zoological Survey of India, Kolkata for facilities; and to Mr. N. Vasudevan, Joint Director, Social Forestry Department, Amaravathi Division for the generous help and co-operation.

\section{OPEN ACGESS I FREE DOWNLOAD (C) (i) (4)}

blunt, digitate and divergent.

\section{Amphizonella violacea Greeff}

1959. Amphizonella violacea

Greeff; Deflandre, Rhizopoda and

Actinopoda (In: Freshwater Biology, Chapter 9: 235 ed. Edmondson.)

Material examined: 22.ix.2007, 1ex. Semodah, coll. L. Bindu.

Diagnosis: Protoplasm violet-tinted with chlorophyllous corpuscles and grains; one nucleus; test patelliform.

Remarks: First report from India.

\section{Family: Arcellidae}

Genus: Pyxidicula Ehrenberg

Diagnosis: Test patelliform; rigid, transparent, punctuate; aperture circular, almost the entire diameter of the test; cytoplasm similar to that of Arcella; a single nucleus; one or more contractile vacuoles.

\section{Pyxidicula operculata (Agardh) Ehrenberg}

1919. Pyxidicula operculata: Cash and Wailes, The British freshwater Rhizopoda and Heliozoa. 4, p.18, figs. 164-168.

Material examined: 22.ix.2007, 2exs. Kolkaz, freshwater, coll. L. Bindu.

Diagnosis: Test smooth, brown; a single vesicular nucleus; pseudopodia short.

Distribution: India: West Bengal

Remarks: First report from Maharashtra.

\section{Family: Centropyxidae}

\section{Genus: Centropyxis Stein}

1859. Centropyxis Stein, Abh. K. Bohm. Gesellsch. Wiss., 10: 43.

1929. Centropyxis Deflandre : Arch. Protistenkd., 67: 322.

Diagnosis: Test dorsoventrally flattened, spheroidal at posterior portion and tapering towards apertural region; oral aperture eccentric or ventral, typically invaginated without a raised rim.

3. Centropyxis ecornis (Ehrenberg, 1841) Leidy, 1879 1841. Arcella ecornis Ehrenberg, Ahb. Akad. Wiss. Berlin, P.368.

1879. Centropyxis ecornis Leidy, Freshwater Rhizopods of North America, pl. 30. figs. 20-24.

1929. Centropyxis ecornis, Deflandre, Arch. Protistenkd., 67, P.359.

Material examined: 22.ix.2007, 4exs., Makhala, freshwater, coll. L. Bindu.

Diagnosis: In ventral view test discoidal or largely elliptical, sometimes irregular in outline, without any spine and covered with quartz grains; in lateral view dorsal surface slightly arched and slightly more elevated 
at posterior part, aperture usually circular, sometimes irregularly lobed and much eccentric.

Distribution: India: Andhra Pradesh, Arunachal Pradesh, Himachal Pradesh, Manipur, Meghalaya, Mizoram, Nagaland, Sikkim, Uttarakhand and West Bengal.

Remarks: First report from Maharashtra.

\section{Centropyxis spinosa (Cash \& Hopkinson, 1905) Deflandre, 1929.}

1905. Centropyxis aculeate var. Spinosa Cash and Hopkinson, The British Freshwater Rhizopoda and Heliozoa, 1, P. 135.

1905. Centropyxis spinosa (Cash and Hopkinson) Deflandre, Arch. Protistenkd., 67. p. 353.

Material examined: 22.ix.2007, 3exs., Makhala, freshwater, coll. L. Bindu.

Diagnosis: Test brownish, more or less circular and considerably flat and furnished with variable number of spines, usually 6-8; spines frequently curved and distributed irregularly on dorsal disc; aperture eccentric, lobate or circular with irregular border; test chitinous with quartz crystals.

Distribution: India: Andhra Pradesh, Arunachal Pradesh, Assam, Himachal Pradesh, Manipur, Meghalaya, Mizoram, Nagaland, Sikkim, Uttarakhand and West Bengal.

Remarks: First report from Maharashtra.

\section{Centropyxis orbicularis Deflandre, 1929}

1929. Centropyxis orbicularis Deflandre, Arch. Protistenkd., 67, P. 334.

Material examined: 22.ix.2007, 1ex. Semodah, freshwater, coll. L. Bindu.

Diagnosis: Test brownish, almost circular in ventral view, ventral surface flat; in lateral view test semicircular, displaying considerable invagination towards the oral aperture; oral aperture nearly semi-circular, plagiostomic; test encrusted with large stony particles on its dorsal border.

Distribution: India: Andhra Pradesh and Uttarakhand. Remarks: First report from Maharashtra.

\section{Genus Cyclopyxis Deflandre, 1929.}

1929. Centropyxis (Cyclopyxis) Deflandre, Arch. Protistenkd., 67, pp. 330, 337.

Diagnosis: Test irregularly arched, oral aperture centrally located.

\section{Cyclopyxis eurystoma (Deflandre, 1929)}

1929. Centropyxis (Cyclopyxis) eurystoma Deflandre, Arch. Protistenkd., 67, p. 371.

Material examined: 22.ix.2007, 1ex., Kolkaz, freshwater. coll. L. Bindu.

Diagnosis: Test hemispherical in lateral view, circular or elliptical in ventral view, brownish, aperture central, circular and slightly invaginated with regular smooth edge and half or little more than half the diameter of the test; test encrusted with quartz particles.

Distribution: India: Arunachal Pradesh.

Remarks: First report from Maharashtra.

Class: Filosea

Order: Gromiida

Family: Euglyphidae

Genus: Assulina Ehrenberg, 1872

1848. Difflugia (Partim) Ehrenberg, Ber. Akad. Berlin, p. 379.

1871 (1872). Assulina (Partim) Ehrenberg, Ber. Akad. Berlin, p. 226.

1879. Assulina: Leidy, Freshwater Rhizopods of North America, p. 224.

Diagnosis: Test brown or colourless, ovoid, compressed, formed of elliptical, imbricated siliceous platelets, arranged more or less regularly in diagonal rows, aperture oval, terminal, truncate or with a short neck bordered by a thin chitinous dentate membrane.

\section{Assulina muscorum Greef, 1888.}

1879. Assulina seminulum (Partim) Leidy, Freshwater Rhizopods of North America, pl. 37. figs.15,16,26.

1915. Assulina muscorum. Cash, Wailes and Hopkinson, The British Freshwater Rhizopoda and Heliozoa, 3, p. 55.

Material examined: 22.ix.2007, 2exs. Kolkaz, freshwater, coll. L. Bindu.

Diagnosis: Test small, yellowish to dark brown and sometimes colourless, oviform, compressed, truncate anteriorly, aperture composed of imbricated oval or elliptical platelets, usually arranged in alternating diagonal rows, sometimes irregularly; aperture terminal, elliptical, bordered by a thin chitinous membrane with undulate or irregularly dentate margin, aperture with pronounced and distinctly lobed collar of organic cement.

Distribution: India: Arunachal Pradesh, Assam, Himachal Pradesh, Manipur, Mizoram, Sikkim, Tripura and West Bengal.

Remarks: First report from Maharashtra.

\section{Assulina seminulum (Ehrenberg, 1848) Leidy,} 1879.

1848. Difflugia seminulum Ehrenberg, Ber. Akad. Berlin, p.379.

1879. Assulina seminulum (Partim) Leidy, Freshwater Rhizopods of North America, p. 225.

Material examined: 22.ix.2007, 1ex. Kolkaz, freshwater, coll. L. Bindu.

Diagnosis: Test about one-and-half times larger in size than that $A$. muscorum, yellowish to dark brown, pyriform or ovoid in broad view, compressed, composed of imbricated oval or elliptical siliceous platelets, aperture terminal, oval, surrounded by a thin chitinous membrane 
Key to the families

1. Test semirigid, flexible near the aperture …............................................ Family Microcoryciidae

- Test rigid

2. Test membranous and rigid, having a distinct oral aperture.....................................Family Arcellidae

- Test with minerals or organic particles and with an oral aperture .................................................

3. Symmetry of test dorso-ventral, oral aperture at one side of the test (eccentric) or Ventral ..................

Family Centropyxidae

\section{Key to the species of Centropyxis}

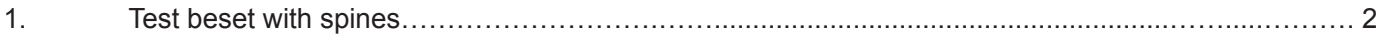

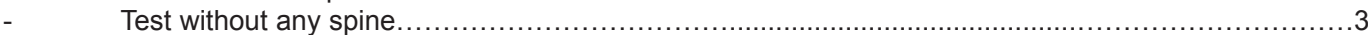

2. Test furnished with variable number of spines frequently curved and distributed irregularly on dorsal side, aperture lobate or circular with irregular border................................................... spinosa.

3. Test comparatively large, discoidal, largely elliptical, usually irregular in outline, oral aperture circular

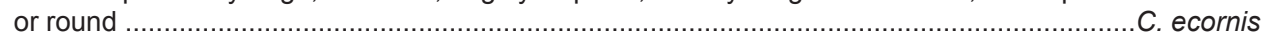
Test circular or nearly circular in ventral view.

4. Test almost circular in ventral view, encrusted with large stony particles on its dorsal border,oral

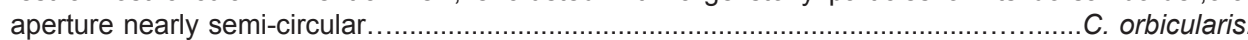

\section{Key to the genera of the family Euglyphidae}

1. Test brown or colourless, aperture elliptical, elongate or oval in oral view, aperture terminal and bordered by very thin and finely dentate membrane ....

Genus Assulina.

2. Test hyaline without any collar, scales of various shape imbricated and arranged in longitudinal rows, aperture terminal and bordered with regularly arranged serrated or denticulated platelets

Genus Euglypha

with irregularly dentate or undulate margin.

Distribution: India: Andhra Pradesh, Assam, Manipur,

Nagaland, Sikkim and West Bengal

Remarks: First report from Maharashtra.

\section{Genus: Euglypha Dujardin, 1841.}

1915. Englypha: Cash, Wailes and Hopkinson, The British Freshwater Rhizopoda and Heliozoa, 3 p. 3.

1962. Euglypha: Decloitre, Arch. Protistenkd., 106, p. 51.

Diagnosis: Test hyaline, ovoid or elongated, formed of circular, oval or scutiform siliceous, imbricated platelets, arranged in alternating longitudinal rows, aperture terminal, circular or elliptic, bordered by serrated or denticulate platelets.

\section{Euglypha acanthophora (Ehrenberg, 1842), Perty,} 1849.

1915. Euglypha acanthophora Cash, Wailes \& Hopkinson, The British Freshwater Rhizopoda and Heliozoa, 3, p.8.

Material examined: 5exs., Makhala, 22.ix.2007, freshwater, coll. L. Bindu.

Diagnosis: Test ovoid or slightly elongated towards aperture, not compressed, aperture circular, bordered by one or occasionally two rows of finely serrated apertural platelets; test platelets elliptical, some platelets of posterior half and at the base of fundus prolonged into spines, spines usually 4-7 in number.

Distribution: India: Andhra Pradesh, Manipur,
Meghalaya, Nagaland and West Bengal.

Remarks: First report from Maharashtra.

10. Euglypha tuberculata Dujardin, 1841.

1915. Euglypha tuberculata Cash, Wailes and Hopkinson, The British Freshwater Rhizopoda and Heliozoa, 3, p. 13. pl. 33, figs. 6-7, pl. 35, figs.3-5, text figs. 112-114.

Material examined: 22.ix.2007, 4exs., Makhala, freshwater, coll. L. Bindu.

Diagnosis: Test elongate-oviform, not compressed, test platelets round or broadly oval, imbricating, giving a regular hexagonal design, aperture circular, bordered by 8-12 finely serrated platelets, arranged in a single row.

Distribution: India: Assam, Andhra Pradesh, Arunachal Pradesh, Himachal Pradesh, Jammu \& Kashmir, Manipur, Meghalaya, Mizoram, Nagaland, Sikkim, Tripura, Uttarakhand and West Bengal.

Remarks: First report from Maharashtra.

\section{REFERENCES}

Cash, J. \& J. Hopkinson (1905). The British Freshwater Rhizopoda Heliozoa. Vol. I, Rhizopoda, Part I. Ray Society, London, 148pp.

Cash, J. \& G.H. Wailes (1915). The British Freshwater Rhizopoda and Heliozoa. Vol. III, Rhizopoda, part III, J. Ray Society, London, 156pp.

Cash, J., G.H. Wailes \& J. Hopkinson (1919). The British Freshwater Rhizopoda and Heliozoa. Vol. IV. Ray Society, London, 130pp. 
Decloitre, L. (1962). Le genere Euglypha Dujardin, Archiv protistenkunde 106(1): 51-100

Deflandre, G. (1929). Le genere Centropyxis Stein. Archiv fuer Protistenkunde 67: 322-375.

Deflandre, G. (1959). Rhizopoda and Actinopoda, pp.232-264. In: Edmondson, W.T. (ed.). Freshwater biology (2 ${ }^{\text {nd }}$ edition). John Wiley and Sons, Inc., New York, London.

Leidy, J. (1879). Freshwater rhizopods of North America. Report of Suvrey of Territories Monograph 12: 1-324pp.

Stein (1859). Characterestic neuer Infusorien-Gattungen. Lotos 9: $2-5$ 